\title{
Geostatistics Application on Uranium Resources Classification: Case Study of Rabau Hulu Sector, Kalan, West Kalimantan
}

\section{Aplikasi Geostatistik pada Klasifikasi Sumber Daya Uranium: Studi Kasus Sektor Rabau Hulu, Kalan, Kalimantan Barat}

\author{
Heri Syaeful*, Suharji \\ Center for Nuclear Minerals Technology-BATAN, \\ Jl. Lebak Bulus Raya No.9, Ps. Jumat, Jakarta, Indonesia, 12440 \\ *E-mail: syaeful@batan.go.id
}

Article received: 13 November 2018, revised: 25 November 2018, accepted: 30 November 2018

DOI: $10.17146 /$ eksplorium.2018.39.2.4960

\begin{abstract}
In resources estimation, geostatistics methods have been widely used with the benefit of additional attribute tools to classify resources category. However, inverse distance weighting (IDW) is the only method used previously for estimating the uranium resources in Indonesia. The IDW method provides no additional attribute that could be used to classify the resources category. The objective of research is to find the best practice on geostatistics application in uranium resource estimation adjusted with geological information and determination of acceptable geostatistics estimation attribute for resources categorization. Geostatistics analysis in Rabau Hulu Sector was started with correlation of the orebody between boreholes. The orebodies in Rabau Hulu Sectors are separated individual domain which further considered has the hard domain. The orebody-15 was selected for further geostatistics analysis due to its wide distribution and penetrated most by borehole. Stages in geostatistics analysis cover downhole composites, basic statistics analysis, outliers determination, variogram analysis, and calculation on the anisotropy ellipsoid. Geostatistics analysis shows the availability of the application for two resources estimation attributes, which are kriging efficiency and kriging variance. Based on technical judgment of the orebody continuity versus the borehole intensity, the kriging efficiency is considered compatible with geological information and could be used as parameter for determination of the resources category.
\end{abstract}

Keywords: geostatistics, uranium resources, IDW, kriging, resources category

\begin{abstract}
ABSTRAK
Pada estimasi sumber daya, metode geostatistik telah banyak digunakan dengan kelebihan adanya alat atribut tambahan untuk mengklasifikasikan kategori sumber daya. Namun demikian, pembobotan inverse distance $(I D W)$ adalah satu-satunya metode yang sebelumnya digunakan untuk mengestimasi sumber daya uranium di Indonesia. Metode IDW tidak memberikan tambahan atribut yang dapat digunakan dalam mengklasifikasikan kategori sumber daya. Tujuan dari penelitian adalah mendapatkan praktek terbaik untuk aplikasi geostatistik pada estimasi sumber daya disesuaikan dengan informasi geologi dan penentuan atribut geostatistik yang dapat digunakan untuk kategorisasi sumber daya. Analisis geostatistik di Sektor Rabau Hulu diawali dengan korelasi tubuh bijih antara lubang bor. Tubuh-tubuh bijih di Sektor Rabau Hulu merupakan domain individual yang selanjutnya dipertimbangkan memiliki domain tegas. Tubuh bijih-15 dipilih untuk digunakan pada analisis geostatistik selanjutnya karena distribusinya yang luas dan paling banyak dipenetrasi bor. Tahapan dalam analisis geostatistik mencakup komposit downhole, analisis statistik dasar, determinasi outliers, analisis variogram, dan perhitungan ellipsoid anisotropi. Analisis geostatistik menghasilkan kemungkinan aplikasi dua atribut estimasi sumber daya, yaitu kriging efisiensi dan kriging varians. Berdasarkan penilaian teknis kemenerusan tubuh bijih terhadap intensitas lubang bor, kriging efisiensi dipertimbangkan sesuai dengan informasi geologi dan dapat digunakan sebagai parameter untuk penentuan kategori sumber daya.
\end{abstract}

Kata kunci: geostatistik, sumber daya uranium, IDW, kriging, kategori sumber daya 


\section{INTRODUCTION}

Geostatistics provides a set of statistical tools for incorporating the spatial and temporal coordinates of observation in data processing [1]. The geostatistical in Earth science has been applied in very broad discipline, such as for study of predicting and simulation soil properties [2], rainfall prediction [3], radon indoor simulation [4], liquefaction probability [5], inferring rock mass rating in tunnel excavation [6], and others.

In resources estimation, geostatistical methods have been widely applied as powerful tools for predicting spatial attributes and for modeling the uncertainty of predictions in un-sampled locations, which are important in mineral resource estimation and ore resources evaluation in many mineral or non-metal commodity, such as for coal, tin, nickel, and iron ore $[7,8,9,10]$. The resources estimation stages involve the definition of mineralization constraints or geological domains, the statistical and/or geostatistical analysis of the sample data, and the application of a suitable grade interpolation technique [11].

In resources estimation projects that have been conducted in several sectors within Kalan area, inverse distance weighting (IDW) has been the tools in resources estimation instead of applying geostatistics [12, 13, 14]. The objective of research is to find the best practice on geostatistical application in uranium resources estimation adjusted with geological information and determination of acceptable geostatistical estimation attribute for resources classification.

\section{METHODOLOGY}

One of the useful criteria for resources classification is the kriging variance or error arising from estimation. This data is seldom used to measure the actual grade confidence (unless the data is strictly normally distributed), the kriging variance depends on the arrangement and continuity of samples around the block, and is a good indicator of overall sample spacing which takes anisotropy and sample clustering into account [8].

Previous research classifies resources in practice and their impact through a sensitivity study using data from a Chilean porphyry copper deposit. Five classification criteria are compared and evaluated, namely: search neighborhoods, absolute kriging variance, relative kriging variances, absolute conditional simulation variance, and relative conditional simulation variances. The result from experience shows methods of statistics give various degree of resources classification which subject to careful consideration of the method [15].

The application of geostatistics was applied on the case study of Rabau Hulu sector in Kalan, West Kalimantan. The first stage of experimental method was collecting exploration data of sectors which covers borehole survey, topography, ore grade, geological map, and geological information on mineralization control. Second stage was input the data into software (Surpac). In the software platform, the interpretation and correlation between peak of uranium anomaly between section and borehole was defined to make a model of orebody.

Selection of representative orebody for further geostatistics analysis was based on number of borehole data that penetrates the orebody. Next stage was statistical analysis of exploratory data analysis to find general information of data and correlation between parameters. Next, the definition and modeling 
of variogram will help with the definition of the basic block size for block modeling techniques, and provide information for the aggregation of grades into larger block sizes, if required [16].

Ordinary Kriging has been used in resource estimation. During geostatistical estimation of block grades, the kriging process provides a measure of error, the kriging variance or the kriging standard deviation [17]. Both of those geostatistics estimation attributes will be used in further definition of resources class.

\section{RESULTS AND DISCUSSION}

Rabau Hulu is a potential sector in Kalan Basin Area, West Kalimantan. Geologically, Kalan covers of Permian-Carboniferous age of metamorphic rocks which is intruded in some parts by alkaline granitic rocks. Stratigraphically, Kalan is divided into 5 units. They are lower series of volcano sedimentary, Rabau quartzite, Kalan Hulu volcanic sediment, Amir Engkala felsic volcanic, and Bukitbiru meta-argillite. The Rabau quartzite composed of quartzite rocks with fine to medium grains, massif dimension with micro-biotite. The uranium mineral is uraninite which is associated with pyrite, molybdenite, chalcopyrite, sphalerite, bornite, magnetite, and tourmaline [18, 19]. The lithology is composed by hornfels, metasiltstone, and feldspathic tuff (Figure 1) [20].

Mineralization is occurred in two styles, controlled by tectonic of fracture filling vein and breccia with strike of $\mathrm{N} 250^{\circ}-260^{\circ} \mathrm{E}$ and dipping of $20-40^{\circ}$, and mineralization which is controlled by magmatic fluid that fills the pore space as discontinuity nodule [21]. The grade of uranium in orebody is resulted from conversion of gamma-ray $\log$ data. In the uranium mining industry, borehole logging is a basic method of exploration and delineation of uranium deposits. Gamma-ray logging is also recognized as the most effective technique to delineate uranium mineralization and estimate uranium ore content [22]. The conversion of gamma-ray log data to uranium grade is done by gamma log interpretation (ILG) procedure. The procedures are to calculate the thickness of the ore by correcting the apparent thickness; to read on the logging to the angle between the mineralized field and the borehole; to calculate the borehole correction factor; to calculate the corrected area; to calculate the apparent grade-thickness; to calculate the average grade-thickness; to calculate the corrected grade; and finally to calculate the grade. The ILG is done separately for each of the mineralized fields read in the gamma log.

The assay databases were arranged based on borehole, the depth of each orebody in the borehole, including the identification of each orebody. Thickness of the orebodies were between $0.1 \mathrm{~m}$ to $5.9 \mathrm{~m}$, with average of 1.10 $\mathrm{m}$. Orebody with a thickness of $5.9 \mathrm{~m}$ was in the R3 borehole (Figure 2). The average grade of all orebodies in total 178 pieces was $0.089 \% \mathrm{eU}_{3} \mathrm{O}_{8}$. The highest level of grade was found in the NC5 borehole of $1.218 \%$ $\mathrm{eU}_{3} \mathrm{O}_{8}$ (Figure 3).

Geological modeling and geostatistics analysis were conducted using the software of Surpac. The first stage was composing database of collar, borehole survey, lithology, and grade. Correlation of orebody was conducted with an average distance between sections of $25-50 \mathrm{~m}$. The correlation was completed only for mineralization which filled the fractured zone or parallel to schistose plane (Figure 4). 


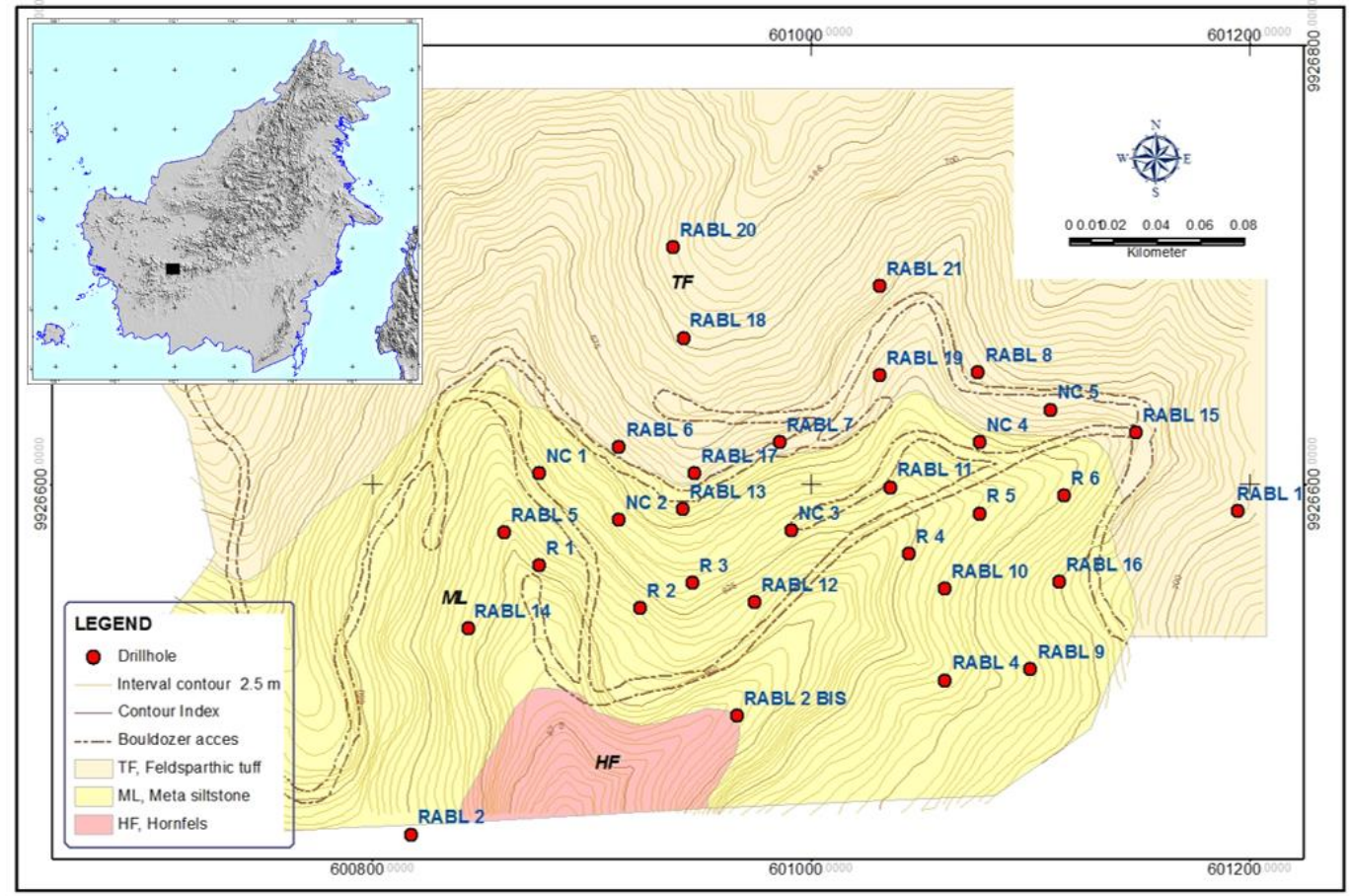

Figure 1. Geological map and boreholes location of Rabau Hulu sector.

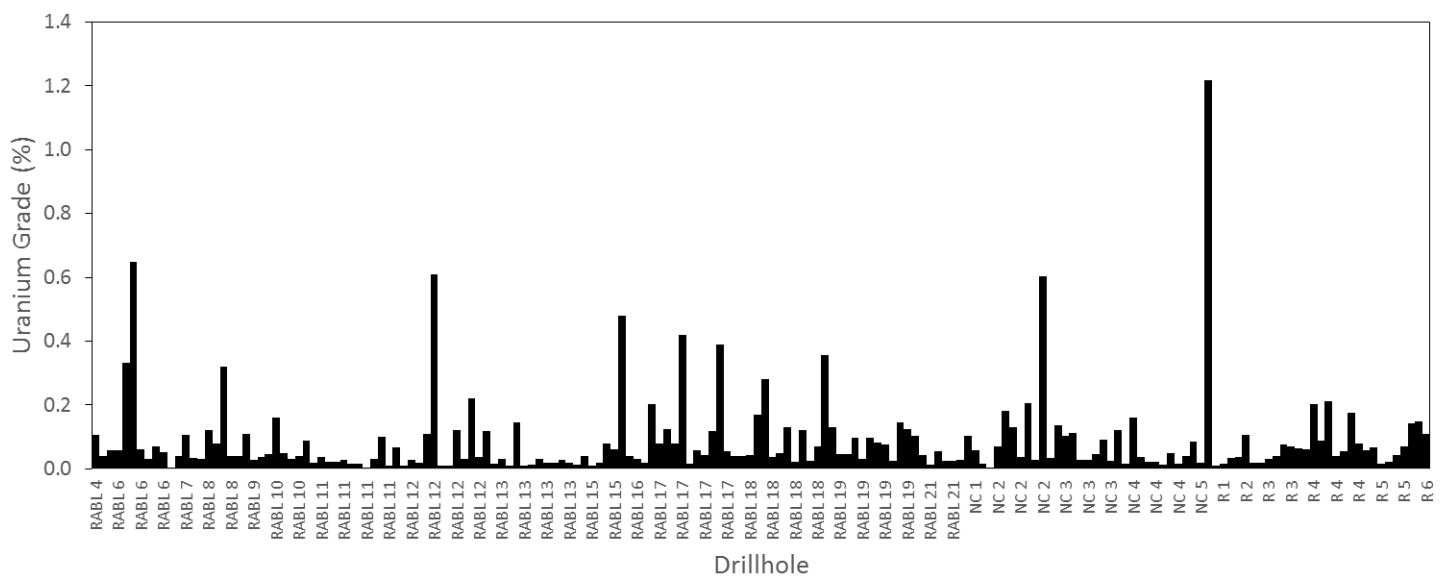

Figure 2. Uranium grade and its boreholes.

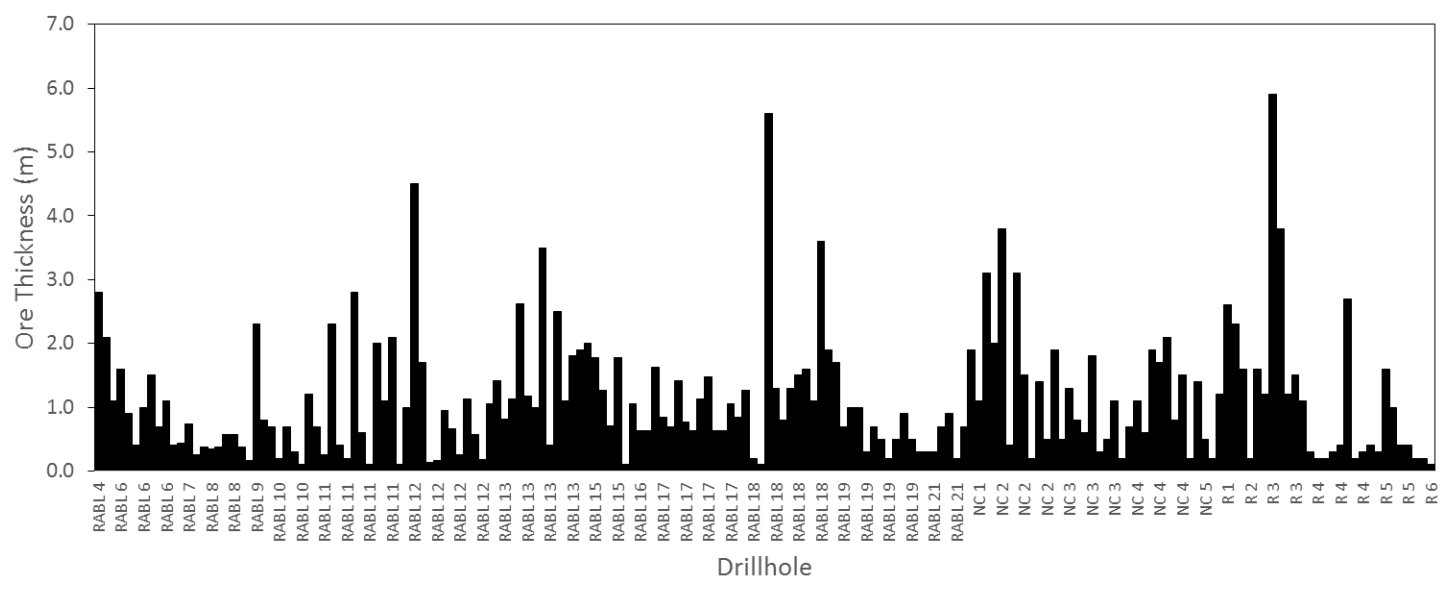

Figure 3. Ore thickness and its borehole. 
Subsequently after geological model was completed based on the available data and knowledge of the setting and genesis of the mineralization; the data were coded accordingly to its domain. A domain in this context is represents an area or volume within, which the characteristics of the mineralization are more similar than outside the domain. It is possible, in defining domains for resource estimation, to impose several types of boundary conditions. Two methods in domain determination are soft domain and hard domain. Soft domain boundaries allow grades from either side of the boundary to estimate both domains, to varying degrees. Hard domain boundaries do not permit interpolation of grades across domains [16].

The domain defined in Rabau Hulu Sector is the hard domain type, which is orebody that had clear boundaries between one another. Based on that fact and the number of sample to be analyzed by geostatistics, the orebody-15 was selected due to have maximum number of orebody grade data (Table 1). Further the orebody-15 was used in geostatistics research application representing the Rabau Hulu sector (Figure 5). Basic statistics of orebody-15 histogram shows the positive skewness, with several higher grade-class data that are separated. Using the formula of $95 \%$ confidence interval (CI), the top cut or outliers is defined as $0.3 \%$ $\mathrm{U}_{3} \mathrm{O}_{8}$. The histogram after top cut is shown in Figure 6.

The variogram is a graph to correlate the degree of similarity between sample grades or other relevant parameters to the distance between them along any given orientation. The experimental variogram values calculated for a given sample separation at a given distance separation, are modeled mathematically using a mineralized spherical model to be measured mathematically. Confidence classification depends on the borehole spacing relative to the range of influence both along strike and down dip [16]. The experimental variogram of grade of orebody-15 was done by omnidirectional with range of sample $25 \mathrm{~m}$. The variogram model is interpreted as nested structure with variance 0.0075 , range $82 \mathrm{~m}$ and $123 \mathrm{~m}$, nugget variance 0.0011 (Figure 7).

Table 1. Uranium grade of Orebody-15.

\begin{tabular}{lcc}
\hline Drillhole & $\begin{array}{c}\text { Thickness } \\
(\mathrm{m})\end{array}$ & $\begin{array}{c}\text { Grade } \\
\left(\% \mathrm{eU}_{3} \mathrm{O}_{8}\right)\end{array}$ \\
\hline NC 1 & 4.22 & 0.057 \\
NC 2 & 1.30 & 0.103 \\
NC 3 & 0.50 & 0.136 \\
NC 4 & 1.90 & 0.023 \\
NC 5 & 1.20 & 0.011 \\
R 4 & 0.30 & 0.212 \\
R 4 & 0.20 & 0.087 \\
R 4 & 0.20 & 0.203 \\
R 4 & 0.30 & 0.079 \\
R 6 & 0.10 & 0.108 \\
RABL 6 & 0.40 & 0.647 \\
RABL 7 & 0.25 & 0.035 \\
RABL 11 & 2.80 & 0.017 \\
RABL 11 & 0.60 & 0.017 \\
RABL 11 & 0.10 & 0.003 \\
RABL 12 & 4.50 & 0.029 \\
RABL 13 & 1.13 & 0.010 \\
RABL 13 & 2.62 & 0.147 \\
RABL 17 & 0.70 & 0.125 \\
RABL 17 & 1.41 & 0.080 \\
RABL 18 & 1.90 & 0.355 \\
\hline
\end{tabular}

The resource estimation was calculated by ordinary kriging (OK) geostatistics method. Prior to estimation, the anisotropy ellipsoid was determined according to orebody geometry, which was bearing 260, plunge 0 , dip -30 , anisotropy ratios of major to semi-major 1, major to minor 8. Minimum number of sample to select was 3 and maximum 12. Maximum searching radius was $25 \mathrm{~m}$ or half of average borehole data distance while maximum search distance was $2.11 \mathrm{~m}$ which was half of maximum ore thickness. 


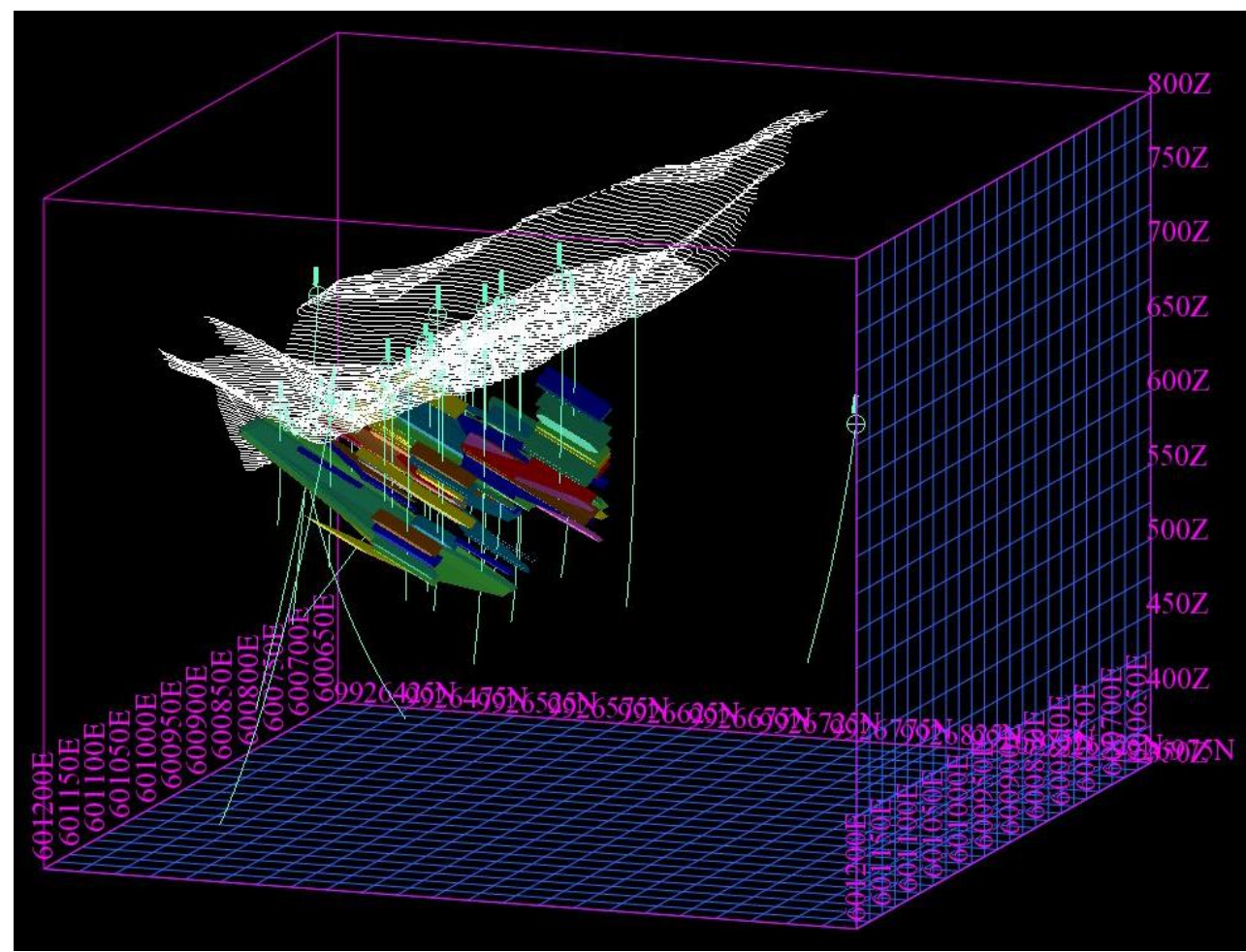

Figure 4. Three dimension model of all orebodies, with topographic and boreholes overlay.

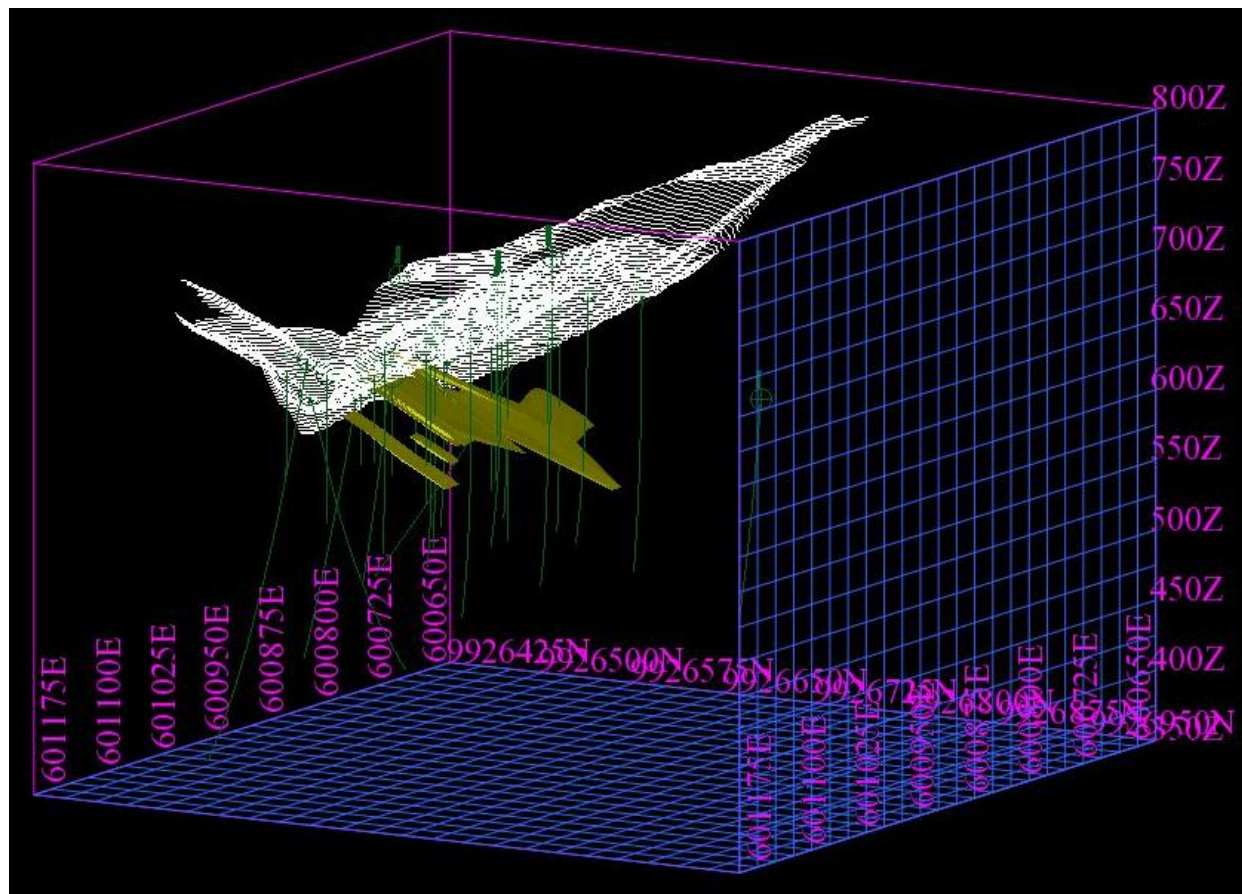

Figure 5. Three dimension model of all orebodies, with topographic and borehole overlay.

Prior to the estimation, geostatistics estimation attribute of kriging efficiency and kriging variance is selected as the output during resources estimation. Further it will be used as a tool in classify the resources class.
Because the kriging error incorporates so many features of both the deposit and data to be used for estimation, it may offer a substantial improvement on block classification over traditional procedures such 
as data density. Practice indicates that the relative kriging standard deviation (RKSD) is particularly useful for block classification in measured, indicated, and inferred categories. The classification using the relative kriging standard deviation (RKSD) is defined as

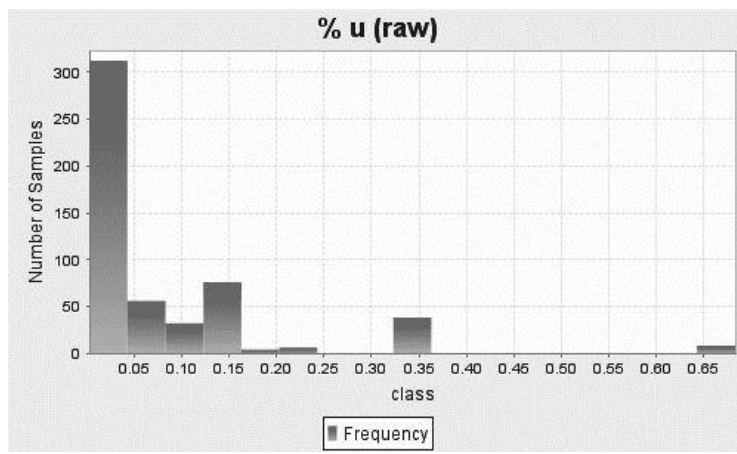

measured $0.3 \leq$ indicated $0.5 \leq$ inferred [17] The other classification method is based on the value of the kriging variance divided by the block variance, where $<0.5$ of the block is classified as Measured, <1.0 classified as Indicated, and Inferred when >1.0 [23].

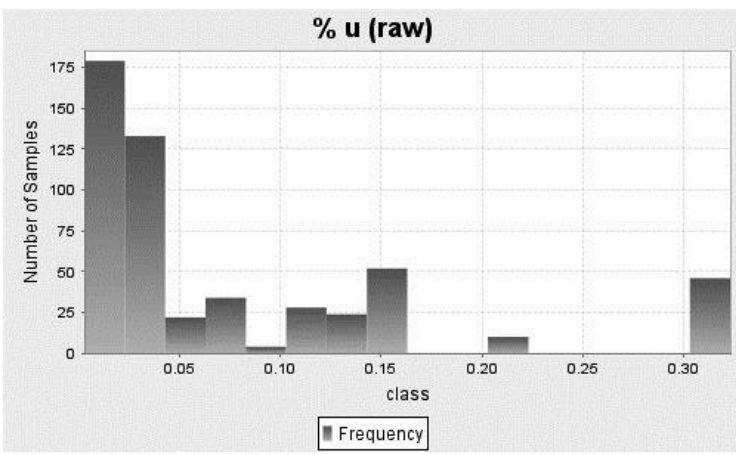

Figure 6. Histogram of uranium grade in orebody-15 (left) and histogram after topcut (right).

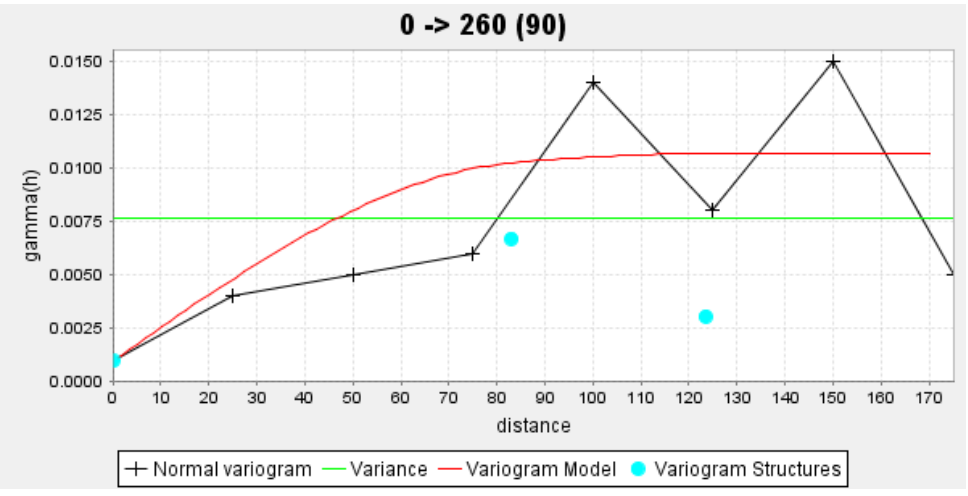

Figure 7. Variogram of orebody.

The result of estimation showed the very different result of resources classification of the two geostatistics estimation attribute. The kriging efficiency is lead to higher class, while the kriging variance (RKSD) to lower class. Table 2 shows the output file from estimation of uranium resources in orebody15. The kriging efficiency had 55.4 ton $(93 \%)$ of measured resources, 4.0 ton $(7 \%)$ of indicated resources, and 0.0 ton $(0 \%)$ of inferred resources. The kriging variance resulted the 0.0 ton $(0 \%)$ of measured, 25.0 ton $(42 \%)$ of indicated resources, and 34.5 ton $(58 \%)$ of inferred resources (Table 3 ). Based on understanding on host rock, uranium mineralization and paragenesis, data density, and degree of confidence on uranium distribution, the result of uranium classification using the kriging efficiency is more appropriate.

Based on the result of geostatistics analysis, it can be concluded that as additional tool besides confidence level on geological control, data integrity, mineralization continuity, and estimation technique, the geostatistics is reliable as a tool to determine the resources classification. The geostatistics is a routine work that has to be done at the time of uranium resource estimation. 
Table 2. Result of orebody-15 resources estimation.

\begin{tabular}{|c|c|c|c|c|c|c|c|c|c|c|c|c|}
\hline \multirow{2}{*}{\multicolumn{3}{|c|}{$\begin{array}{c}\text { Uranium Grade } \\
\qquad(\% \mathrm{eU})\end{array}$}} & \multirow{3}{*}{$\begin{array}{c}\begin{array}{c}\text { Ore } \\
\text { Volume } \\
\left(\mathrm{m}^{3}\right)\end{array} \\
6,788\end{array}$} & \multirow{3}{*}{$\begin{array}{c}\begin{array}{c}\text { Ore } \\
\text { Tonnage } \\
(\mathrm{t})\end{array} \\
18,804\end{array}$} & \multirow{3}{*}{$\begin{array}{l}\begin{array}{l}\text { Grade } \\
(\% \mathrm{eU})\end{array} \\
0.02\end{array}$} & \multirow{3}{*}{$\begin{array}{c}\begin{array}{c}\mathrm{U} \\
\text { Tonnage } \\
(\mathrm{t})\end{array} \\
3.03\end{array}$} & \multicolumn{3}{|c|}{ Resources Classification (Young, 2008) } & \multicolumn{3}{|c|}{ Resources Classification (Blackwell, 1999) } \\
\hline & & & & & & & \multirow{2}{*}{$\begin{array}{r}\begin{array}{c}\text { Kriging } \\
\text { Efficiency }\end{array} \\
0.59\end{array}$} & \multirow{2}{*}{$\begin{array}{r}\% \text { Error } \\
59.00\end{array}$} & \multirow{2}{*}{$\begin{array}{l}\text { Resource } \\
\text { Category } \\
\text { Measured }\end{array}$} & \multirow{2}{*}{$\begin{array}{r}\begin{array}{c}\text { Kriging } \\
\text { Variance }\end{array} \\
0.004\end{array}$} & \multirow{2}{*}{$\begin{array}{r}\text { RKSD } \\
7.86\end{array}$} & \multirow{2}{*}{$\begin{array}{c}\text { Resource Category } \\
\text { Inferred }\end{array}$} \\
\hline 0.01 & - & 0.02 & & & & & & & & & & \\
\hline 0.02 & - & 0.03 & 1,680 & 4,653 & 0.03 & 1.35 & 0.68 & 67.50 & Measured & 0.003 & 3.78 & Inferred \\
\hline 0.03 & - & 0.04 & 844 & 2,338 & 0.04 & 0.82 & 0.43 & 42.50 & Indicated & 0.005 & 4.04 & Inferred \\
\hline 0.04 & - & 0.05 & 37 & 102 & 0.04 & 0.05 & 0.69 & 69.30 & Measured & 0.003 & 2.47 & Inferred \\
\hline 0.05 & - & 0.06 & 1 & 4,017 & 0.06 & 2.29 & 0.61 & 60.50 & Measured & 0.003 & 1.92 & Inferred \\
\hline 0.06 & - & 0.07 & 53 & 147 & 0.07 & 0.10 & 0.65 & 64.80 & Measured & 0.003 & 1.59 & Inferred \\
\hline 0.07 & - & 0.08 & 465 & 1,288 & 0.08 & 1.02 & 0.58 & 57.50 & Measured & 0.004 & 1.60 & Inferred \\
\hline 0.08 & - & 0.09 & 430 & 1,192 & 0.08 & 0.97 & 0.61 & 61.10 & Measured & 0.003 & 1.34 & Inferred \\
\hline 0.09 & - & 0.10 & 112 & 309 & 0.10 & 0.30 & 0.60 & 59.60 & Measured & 0.004 & 1.32 & Inferred \\
\hline 0.10 & - & 0.11 & 2,602 & 7,208 & 0.10 & 7.46 & 0.60 & 60.00 & Measured & 0.004 & 1.22 & Inferred \\
\hline 0.11 & - & 0.12 & 91 & 252 & 0.11 & 0.28 & 0.60 & 60.30 & Measured & 0.004 & 1.12 & Inferred \\
\hline 0.12 & - & 0.13 & 631 & 1,747 & 0.12 & 2.16 & 0.61 & 60.60 & Measured & 0.003 & 0.89 & Inferred \\
\hline 0.13 & - & 0.14 & 737 & 2,040 & 0.14 & 2.78 & 0.49 & 48.50 & Indicated & 0.005 & 1.04 & Inferred \\
\hline 0.14 & - & 0.15 & 1,643 & 4,550 & 0.15 & 6.69 & 0.63 & 63.20 & Measured & 0.003 & 0.75 & Inferred \\
\hline 0.15 & - & 0.16 & 94 & 260 & 0.16 & 0.41 & 0.47 & 47.20 & Indicated & 0.005 & 0.90 & Inferred \\
\hline 0.16 & - & 0.17 & 469 & 1,299 & 0.16 & 2.14 & 0.63 & 62.90 & Measured & 0.003 & 0.66 & Inferred \\
\hline 0.17 & - & 0.18 & 340 & 941 & 0.17 & 1.64 & 0.71 & 71.30 & Measured & 0.003 & 0.63 & Inferred \\
\hline 0.18 & - & 0.19 & 40 & 110 & 0.19 & 0.21 & 0.70 & 69.60 & Measured & 0.003 & 0.59 & Inferred \\
\hline 0.19 & - & 0.20 & 53 & 147 & 0.19 & 0.29 & 0.66 & 66.30 & Measured & 0.003 & 0.56 & Inferred \\
\hline 0.20 & - & 0.21 & 28 & 78 & 0.21 & 0.16 & 0.64 & 64.40 & Measured & 0.003 & 0.53 & Inferred \\
\hline 0.21 & - & 0.22 & 58 & 162 & 0.21 & 0.35 & 0.53 & 53.10 & Measured & 0.004 & 0.59 & Inferred \\
\hline 0.22 & - & 0.23 & 40 & 110 & 0.23 & 0.25 & 0.67 & 66.60 & Measured & 0.003 & 0.48 & Indicated \\
\hline 0.23 & - & 0.24 & 30 & 82 & 0.23 & 0.19 & 0.67 & 66.50 & Measured & 0.003 & 0.47 & Indicated \\
\hline 0.31 & - & 0.32 & 2,854 & 7,904 & 0.31 & 24.52 & 0.54 & 53.50 & Measured & 0.004 & 0.41 & Indicated \\
\hline \multicolumn{3}{|c|}{ Total } & 21,568 & 59,742 & 0.100 & 59.44 & 0.59 & 58.80 & Measured & 0.004 & 1.27 & Inferred \\
\hline
\end{tabular}

Table 3. Resume of result of orebody-15 resources estimation and classification.

\begin{tabular}{cccc}
\hline Parameter & Measured & Indicated & Infered \\
\hline Kriging Efficiency & $93 \%$ & $7 \%$ & $0 \%$ \\
RKSD & $0 \%$ & $42 \%$ & $58 \%$ \\
\hline
\end{tabular}

\section{CONCLUSION}

The application of geostatistics in resources estimation is important to understand the spatial correlation between parameters and lead the best estimation techniques. However the information concerning geological control, mineralization continuity, and economic sensitivity are the most important thing in the assessment of resource estimation technique and resource classification. In term of uranium deposits in Rabau Hulu Sector, geostatistics analysis in Rabau Hulu Sector was started with correlation of the orebody between boreholes. The orebodies in Rabau Hulu Sectors was defined as separated individual domain or further considered has the hard domain.
Stages in geostatistics analysis covers downhole composites within domain, perform basic statistics, outlier analysis, variogram analysis, and calculate the anisotropy ellipsoid. Afterward the resources estimation applied with block model size adjusted with ore size. The result of geostatistics, which is estimation attribute of kriging efficiency preferably used as additional information in determination of resources category.

\section{ACKNOWLEDGMENT}

Many thanks to the Head of PTBGNBATAN, Mr. Agus Sumaryanto for supporting this research and Dr. M. Nur Heriawan for assisting in geostatistics analysis. 


\section{REFERENCES}

[1] P. Goovaerts, Geostatistics for Natural Resources Evaluation. New York, 1997.

[2] H. Yan and H. Moradkhani, "Combined assimilation of streamflow and satellite soil moisture with the particle filter and geostatistical modeling," Adv. Water Resour., vol. 94, pp. 364378, 2016.

[3] A. M. .C. Wadoux, D. J. Brus, M. A. RicoRamirez, and G. B. M. Heuvelink, "Sampling design optimisation for rainfall prediction using a non-stationary geostatistical model," Adv. Water Resour., vol. 107, pp. 126-138, 2017.

[4] C. Cafaro, C. Giovani, and M. Garavaglia, "Geostatistical simulations for radon indoor with a nested model including the housing factor," $J$. Environ. Radioact., vol. 151, pp. 264-274, 2016.

[5] H. Zou, S. Liu, G. Cai, T. V. Bheemasetti, and A. J. Puppala, "Mapping probability of liquefaction using geostatistics and first order reliability method based on CPTU measurements," Eng. Geol., vol. 218, pp. 197-212, 2017.

[6] J. Chen, X. Li, H. Zhu, and Y. Rubin, "Geostatistical method for inferring RMR ahead of tunnel face excavation using dynamically exposed geological information," Eng. Geol., vol. 228, no. December 2016, pp. 214-223, 2017.

[7] B. Sadeghi, N. Madani, and E. J. M. Carranza, "Combination of geostatistical simulation and fractal modeling for mineral resource classification," J. Geochemical Explor., vol. 149, pp. 59-73, 2015.

[8] F. Atalay and A. E. Tercan, "Coal resource estimation using Gaussian copula," Int. J. Coal Geol., vol. 175, no. January, pp. 1-9, 2017.

[9] M. E. Hohn and J. Q. Britton, “A geostatistical case study in West Virginia: All coals are not the same," Int. J. Coal Geol., vol. 112, pp. 125-133, 2013.

[10] M. N. Heriawan and K. Koike, "Identifying spatial heterogeneity of coal resource quality in a multilayer coal deposit by multivariate geostatistics," Int. J. Coal Geol., vol. 73, pp. 307330, 2008.

[11] M. G. Deng, W. C. Li, B. Li, L. H. Li, S. De Jiang, G. X. Xiong, X. S. Zhang, and H. J. Yu, "Application of Log Kriging on Estimated Reserves of the 10-9 Ore Body of Lutangba in the Gejiu Tin Deposits," J. China Univ. Min. Technol., vol. 17, no. 2, pp. 286-289, 2007.
[12] Suharji, "Re-evaluasi Sumber Daya Uranium di Sektor Semut, Kalan, Kalimantan Barat," in Prosiding Seminar Nasional Geologi Nuklir dan Sumber Daya Tambang Tahun 2014, pp. 35-50, 2014.

[13] H. Syaeful, Suharji, and A. Sumaryanto, "Pemodelan Geologi dan Estimasi Sumber Daya Uranium di Sektor Lemajung, Kalan, Kalimantan Barat," in Prosiding Seminar Nasional Teknologi Energi Nuklir Tahun 2014, pp. 329-342, 2014.

[14] A. G. Muhammad and B. Soetopo, "Pemodelan dan Estimasi Sumber Daya Uranium di Sektor Lembah Hitam, Kalan, Kalimantan Barat," Eksplorium, vol. 37, no. 1, pp. 1-12, 2016.

[15] X. Emery, J. M. Ortiz, and J. J. Rodríguez, "Quantifying uncertainty in mineral resources by use of classification schemes and conditional simulations," Math. Geol., vol. 38, no. 4, pp. 445-464, 2006.

[16] I. M. Glacken and D. V. Snowden, "Mineral Resource Estimation," in Mineral Resources and Ore Reserve Estimation - The AusIMM Guide to Good Practice, A. C. Edwards, Ed. Melbourne: The Australasian Institute of Mining and Metallurgy, pp. 189-198, 2001.

[17] G. Blackwell, "Relative kriging errors - A basis for mineral resource classification," Explor. Min. Geol., vol. 7, no. 1, pp. 99-105, 1999.

[18] S. Tjokrokardono, B. Sutopo, L. Subiantoro, and K. Setiawan, "Geologi dan Mineralisasi Uranium Kalan, Kalimantan Barat," in Kumpulan Laporan Hasil Penelitian Tahun 2005, pp. 27-52, 2005.

[19] B. Soetopo, R. Witjahyati, and Y. Wusana, "Synthesis on Geology and Uranium Mineralization of Rabau Hulu Sector, Kalan, West Kalimantan," in Seminar Geologi Nuklir dan Sumberdaya Tambang Tahun 2004, pp. 8499, 2004.

[20] N. Mery, X. Emery, A. Cáceres, D. Ribeiro, and E. Cunha, "Geostatistical modeling of the geological uncertainty in an iron ore deposit," Ore Geol. Rev., vol. 88, pp. 336-351, 2017.

[21] V. Snowden, "Practical interpretation of resource classification guidelines," AusIMM 1996 Аnnu. Conf., no. 09, pp. 1-16, 2000.

[22] C. J. Mwenifumbo and A. L. Mwenifumbo, Geophysical logging methods for uranium geology and exploration. Geological Survey of Canada, Technical Note 4, 2013. 
Geostatistics Application On Uranium Resources Classification:

Case Study Of Rabau Hulu Sector, Kalan, West Kalimantan

By: Heri Syaeful and Suharji

[23] D. R. Young, "The effect of ignoring the sample support on the global and local mean grade estimates, mineral resource classification and project valuation of variable width Merensky and UG2 Reef orebodies," Third Int. Platin. Conf., no. 2006, pp. 63-76, 2008. 